\title{
THE FAMILY GALLIENIELLIDAE (ARANEAE, GNAPHOSOIDEA) IN THE AMERICAS
}

\author{
Pablo A. Goloboff: Consejo Nacional de Investigaciones Científicas y Técnicas, \\ Instituto Miguel Lillo, Miguel Lillo 205, 4000 S. M. de Tucumán, Argentina
}

\begin{abstract}
Azilia leucostigma Mello-Leitão 1941 considered by Mello-Leitão as a metine (Tetragnathidae), is transferred to the gnaphosoid family Gallieniellidae, as the type species of the new genus Galianoella. The obliquely depressed endites, the flattened irregular posterior median eyes, and the conical anterior lateral spinnerets retaining a sclerotized distal ring, among other characters, clearly place the new genus in the family Gallieniellidae. Galianoella leucostigma is the only gallieniellid so far recorded from the Americas. This species has a specialized ant-preying behavior. Ant-preying may prove to be characteristic for all the family, as it was suspected in the Madagascan Gallieniella; and it may be associated with the modified chelicerae typical of the family.
\end{abstract}

Keywords: Spiders, arachnids, Galianoella

The family Gallieniellidae is a small family of dionychan spiders recorded so far only for Madagascar, the Comoro Islands, southern Africa, and Australia. Only a handful of papers have dealt with the group. Platnick (1984) summarized its taxonomic history and revised the family, describing several new species and the genus Legendrena; Platnick (1990b) added some species in Gallieniella Millot 1947 and Legendrena; Platnick (1990a) transferred Drassodella Hewitt 1916 from the Gnaphosidae and mentioned the existence of undescribed genera of Australian gallieniellids.

The gallieniellids have the obliquely depressed endites and flattened irregular posterior median eyes typical of the Gnaphosoidea, but they are probably the sister group of most other gnaphosoids because they have the anterior lateral spinnerets conical and more closely set than in most other gnaphosoid families and retain an apical segment (Platnick 1984, 1990a). These spiders are quite uncommon in collections, and very little is known of their biology. During recent years, several specimens of Gallieniellidae have been collected in dry and semi-arid habitats of northwestern Argentina. These were first thought to represent an undescribed genus and species. The species, however, had been described (as a metine tetragnathid!) by Mello-Leitão (1941), with the name Azilia leucostigma, which is here designed as the type species of the new genus Galianoella. Although Mello-
Leitão gave measurements for both the male and the female of A. leucostigma, the female was not illustrated, and the only specimen now available seems to be the male holotype.

The abbreviations used in this study are standard for the Araneae. The notation for leg spines is as in Goloboff (1995). The specimens examined are deposited in the Instituto and Fundación Miguel Lillo, Tucumán, (FIML); Museo Argentino de Ciencias Naturales, Buenos Aires, (MACN); Museo de Ciencias Naturales, La Plata (MLP); and American Museum of Natural History, New York (AMNH).

\section{Galianoella new genus}

Type species.-Azilia leucostigma MelloLeitão 1941.

Etymology.-It is a pleasure to name the new genus after María E. Galiano, who introduced me to arachnology, with gratitude for her continued help and advice, and in recognition of her contributions to arachnology.

Diagnosis.-Galianoella can be distinguished easily from other gallieniellid genera by the membranose area on the cheliceral margins (Fig. 3), and the eyes occupying a wider portion of the head (Figs. 1, 2). Females can be distinguished also by the laterally depressed palpal tibia with strong prolateral spines (Fig. 4) and the wrinkled membranous posterior extensions of the epigynum (Fig. 6). Males can be recognized by the complex pal- 


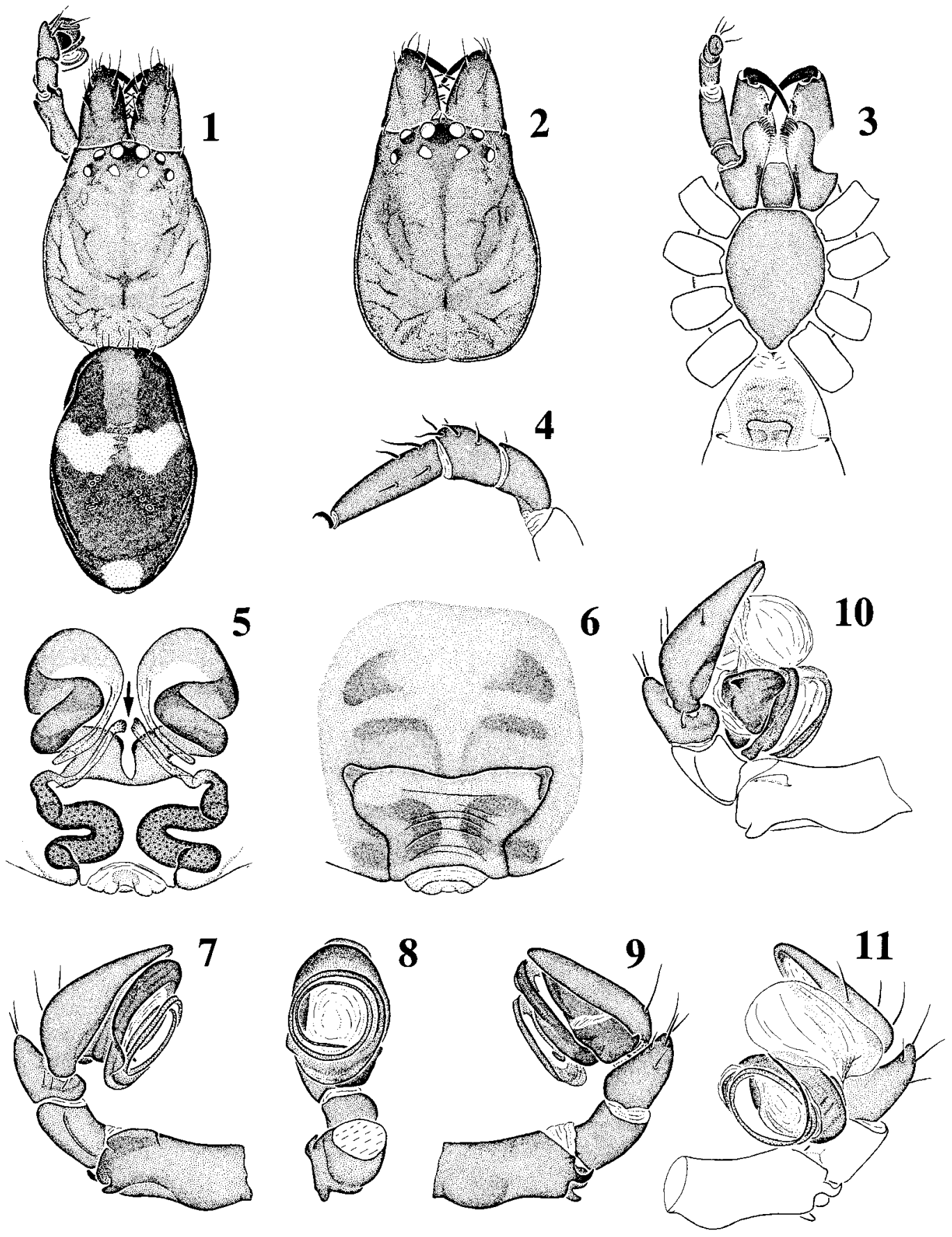

Figures 1-11.-Galianoella leucostigma. 1, Dorsal view, male; 2, Dorsal view, female; 3, Ventral view, female; 4, Right female palp, prolateral; 5, Spermathecae; 6, Epigynum; 7-9, Right male palp, bulb in resting position; 10, 11, Right male palp, bulb expanded. 

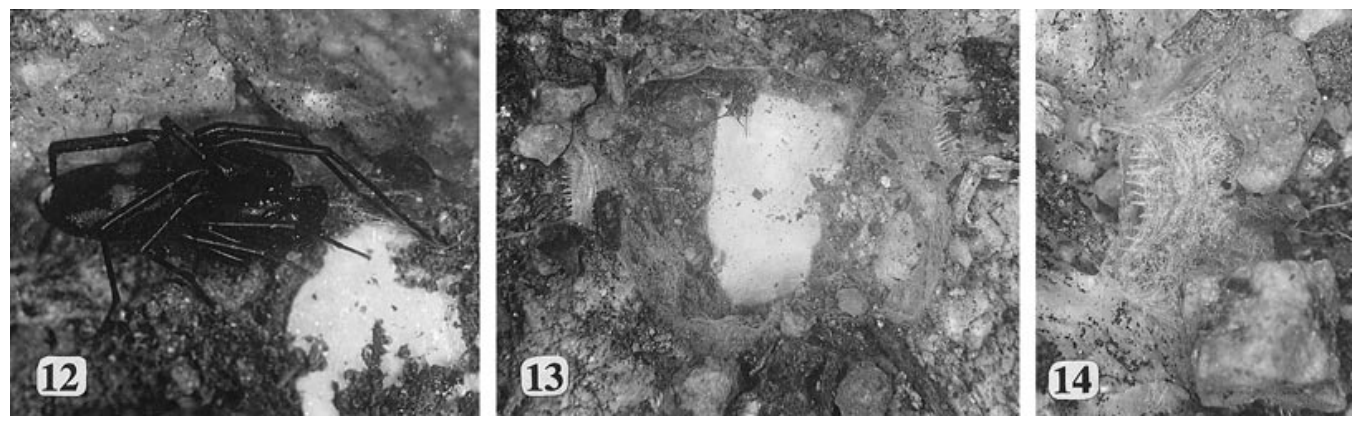

Figures 12-14._-Galianoella leucostigma. 12, Female with egg-sac; 13, Cell; 14, Detail of cell entrance.

pal femoral apophyses and keel (Figs. 7-9; absent in other genera of the family) and by the spiralled tegulum coiling aroung an extensive distal haematodocha (Figs. 8, 11).

Description.-See species description.

Relationships. - Their reduced number of cylindrical gland spigots suggests that Legendrena and Gallieniella are sister groups; in different gnaphosoid families, as well as in Galianoella and Drassodella, those spigots are usually fairly numerous (and often arranged in longitudinal rows; see Platnick 1990a). The eyes are set on a low tubercle in Gallieniella, Legendrena, and Drassodella, but are completely sessile and occupy most of the cephalic width in Galianoella and nongallieniellid gnaphosoids, suggesting that Galianoella is the sister group of the other three genera.

The hypothesis of relationsips just proposed, however, is far from well supported, as it is contradicted by the elongated and inclined chelicerae of Gallieniella and Galianoella. Drassodella and Legendrena have shorter, more vertical chelicerae, which suggests that Galianoella and Gallieniella are sister genera.

Besides the wider eye group, there are several other characters in which Galianoella differs from all other gallieniellids, but they are most parsimoniously interpreted as its autapomorphies. These autapomorphies include the membranose cheliceral areas, the interior cheliceral faces with short spiniform setae, the undifferentiated cheliceral margins, the ventral spines on patellae, the wrinkled posterior epigynal extensions with a cavity, the ringlike tegulum with an extensive haematodocha, the modified female palpal tibia bearing strong prolateral setae, and the modified male palpal femur. Although its absence in the other gallieniellid genera cannot be ascertained from published illustrations of male palps, the subtegular projection is absent in Gallieniella (the only genus for which I have examined males). Thus, this projection may be another autapomorphy of Galianoella.

\section{Galianoella leucostigma (Mello-Leitão 1941) new combination}

Figs. 1-14

Azilia leucostigma Mello-Leitão, 1941: 155, fig. 50, pl. 7, fig. 33 (male holotype, from Argentina, Province of Salta, Salta, M. Birabén col., no date, MLP 14808, examined).

Diagnosis.-See diagnosis for genus.

Description.--Female: (From Chuscha). Total length 5.91 (6.78 with chelicerae). Cephalothorax (Fig. 2) 2.34 long, 1.83 wide. Cephalic region almost flat, 1.62 long, 1.38 wide. Eyes occupying 0.78 of head width, in two recurved rows; AME rounded, convex, on low common elevation; all other eyes completely sessile; PME irregular, flattened, with diffuse limits. Chelicerae elongated (Fig. 3), with long fang, with about 60 small spiniform setae on interior face, larger and stronger near anterior face. Chelicerae distally narrow, with pro- and retromargins not well differentiated; with membranose area apically wider (visible only from below); single, large (retromarginal?) tooth and 2 small denticles set on common sclerotized elongate patch in the middle of this membranose area, 2 or 3 small (promarginal?) denticles on apex. Endites long, medially constricted; labium 0.56 long, 0.42 wide, flat; sternum 2.60 long, 1.20 wide. Intercoxal bridges not visible. Palpi (Fig. 4) short; tibia short, laterally compressed, with strong prolateral erect setae. Legs long, slen- 
Table 1.-Leg measurements (in $\mathrm{mm}$ ) of Galianoella leucostigma.

\begin{tabular}{cccccc}
\hline Female & Femur & Patella + Tibia & Metatarsus & Tarsus & Total \\
\hline I & 2.16 & 2.76 & 2.07 & 1.20 & 8.19 \\
II & 1.98 & 2.46 & 1.98 & 1.11 & 7.53 \\
III & 1.83 & 2.28 & 1.80 & 0.84 & 6.75 \\
IV & 2.28 & 2.91 & 2.43 & 1.08 & 8.70 \\
Palp & 0.72 & 0.72 & - & 0.66 & 2.10 \\
Male & Femur & Patella + Tibia & Metatarsus & Tarsus & Total \\
\hline I & 2.12 & 2.76 & 2.12 & 1.24 & 8.24 \\
II & 2.00 & 2.28 & 2.00 & 1.08 & 7.36 \\
III & 1.88 & 2.24 & 1.80 & 0.88 & 6.80 \\
IV & 2.40 & 2.92 & 2.44 & 1.04 & 8.80 \\
Palp & 0.76 & 0.72 & - & 0.76 & 2.24 \\
\hline
\end{tabular}

der; tarsi ascopulate, without claw-tufts; with few, weak spines. Measurements: See Table 1.

Chaetotaxy: Femora: I, 1 D (1:3 AP), 1 P SUP (1:4 AP); II-IV, 1-1-0 D; palp, 1 p (1:4 ap). Patellae: I, II, $1 \mathrm{~d}$ ap (thin, erect, on the condyle joining patella and tibia), $1 \mathrm{v}$ post $\mathrm{b}$; III, IV, $1 \mathrm{~d}$ ap (as in I, II), $0 \mathrm{v}$; palp, $1 \mathrm{~d}$ ap (weaker than in I, II). Tibiae: I, II, 0; III, $1 \mathrm{~d}$ (1:4 ap), 1 V ANT (1:5 B), 2 V AP; IV, 1 d (1:4 ap), 1-1-1 V ANT, 1 V POST AP; palp, 3 P SUP A (erect, curved), $3 \mathrm{P}$ (shorter). Metatarsi: I, II, 0; III, IV, 1 V ANT (1:3 B). Tarsi: I-IV, 0; palp, numerous erect thin setae on $\mathrm{V}$ and $\mathrm{P}, 1-1 \mathrm{D}$ ANT B, 1-1 P (1:3 B).

Palpal tibia laterally compressed (i.e., wider dorso-ventrally). Superior tarsal claws with single row of 3 teeth (basal one of III and IV bifid); third claw absent from all tarsi; palpal claw with 3 teeth, increasing in size from basal to distal. ALS conical, with distal sclerotized ring, with 2 spigots (with short, rather wide shaft distinctly separated from base; possibly corresponding to piriform glands, not SEM examined); PMS with larger spigot on apex (with base larger than shaft), plus 7 slightly smaller ones (possibly cylindrical, as they are absent in the male) on the dorsal face, in two alternate rows; PLS with 2 closely-set spigots on anterior edge, plus one medial spigot.

Coloration: Cephalothorax and legs reddish-brown; abdomen dorsally black, with two dorsal and single posterior yellow-cream areas; venter pale, darker laterally and around spinnerets. Epigynum: (Fig. 6). Large sclerotized plate, with posterior membranous wrinkles, with posterior opening connecting to in- ternal cavity (apparently glandular). Spermathecae (Fig. 5) reniform; portion of copulatory ducts distal to spermathecae strongly sclerotized, spiralled; proximal portion twisted around most distal one, with medial glandular area (Fig. 5, arrow near strongly sclerotized edges of distal portion).

Male: (Chuscha). As in female, except as noted: Total length 5.31 (5.91 with chelicerae). Cephalothorax (Fig. 1) 2.40 long, 1.83 wide. Cephalic region 1.56 long, 1.32 wide. Eyes occupying 0.77 of head width. Labium 0.56 long, 0.42 wide; sternum 2.43 long, 1.20 wide. Leg measurements: see Table 1. Chaetotaxy: As in female, except: Tibiae III, IV, 11-2/1-0-1 V ANT, 1 V POST AP, 1 d (1:4 ap); palpal tibia with 5 setae on apex; cymbium with some thickened spiniform dorsal setae. Abdomen (Fig. 1) with dorsal anterior scutum. Spinnerets as in female; ALS spigots as in female; PMS and PLS with single large apical spigot. Palp (Figs. 7-11): Three dorsal apical apophyses on femur: anterior one pointed and strongly sclerotized, posterior one blunt, middle one rounded; retroventral apical keel on femur; retrolateral longitudinal keel on patella; tibia with dorsal long projection bearing strong setae. Bulb: Subtegulum very large, visible in prolateral view (Fig. 9), with small projection (Fig. 10) anchoring in the anterior basal rim of the cymbium; tegulum spiraled, almost continuous with strip-like spiralled embolus, coiling around large distal haematodocha occupying central position (Figs. 8, 11).

Natural history.-Galianoella lives under stones or logs, in arid or semi-arid habitats. The specimens were found in small silk cells 
up to $2 \mathrm{~cm}$ long, $1 \mathrm{~cm}$ wide, sometimes covered with debris and prey remains, with two entrances. The entrances had a peculiar structure, with two small parallel flaps, each about $4 \mathrm{~mm}$ wide and with 15 small finger-like bars (formed by either a single thick thread, or several thinner threads compacted or cemented by some substance). These bars are about 1.5 $\mathrm{mm}$ long (half of which is imbedded in the silk mat), roughly parallel, and give the cell entrance the appearence of a double comb. Perhaps these peculiar combs help prevent ants from entering the refuge. The egg-sac is flattened, lenticular, 8-9 $\mathrm{mm}$ in diameter, with an internal white papery layer (as in many other gnaphosoids) and an outer layer of loose much thicker threads. Several cells contained more than a single egg-sac.

The living specimens, although not definitely myrmecomorph, have a strong ant-like appearance. They do not use their first legs as antennae (as many ant-mimicks do), but walk in a somewhat ant-like way; the resemblance to an ant is strengthened by the paler dots on the abdomen, which give the impression of a constriction. Especially because of the way they move, the first impression on seeing specimens in the field is of cell-living castaneirine corinnids with unusually long chelicerae and unusually bright PME (castaneirines do not live in cells, and have short vertical chelicerae and normal PME).

In captivity, the specimens were observed to feed only on ants. A few other items of prey were offered, but ignored. The cells of Galianoella often contained Camponotus remains (Formicidae, Formicinae), and it is likely that adults prey upon them; in captivity, the spiders were fed Acromyrmex (a leaf-cutting ant, Myrmicinae) and soldiers of Pheidole (the European fire ant, also a myrmicine). The Madagascan Galieniella have been collected together with ants, and it was suspected that they could prey upon them, but no actual observations exist.

The capture sequence in Galianoella is very stereotyped. The spider always attacks the ant from behind, placing its fangs on the sides of the ant's thorax. When the ant was not facing away from the spider (the most common situation), the spider positioned herself, moving around the ant sideways (i.e., always facing the ant), in an arc about $1 \mathrm{~cm}$ in diameter; when the ant continued crawling (which happened most of the times), the spider followed the ant in the same manner for a few centimeters until she could position herself in a proper position to attack. While pursuing the ant, the spider walked on six legs, with her chelicerae wide open, the palpi raised and retracted, and the extended anterior legs raised at an angle of about $45^{\circ}$.

It is possible that the large tooth set on the sclerotized plate on the membranous cheliceral patch and/or the spine-like setae on the inner chelicerae (together with the palpi, see below) play a special role in holding the ant after the attack. It is also possible that the spider fangs were not actually piercing the ant's exoskeleton at this time (a couple catches were observed under the microscope, under low magnification); rather, the fangs seemed to embrace the ant's thorax and coxae, holding the thorax pressed against the basal article of the chelicerae. Sometimes the spider held the ant in this way for only an instant, quickly releasing and following it until it died (always within a few seconds). Often, the spider did not release the ant at all; while holding the ant, the spider palpi were put downwards (with apical articles directed posteriorly), such that the tibial spines when pressed against the ant's abdomen, and the ant's abdomen could then only curve downwards. The spider palpi were then not visible from above. Careful examination of the ant remains under light magnification (about $50 \times$ ) revealed no holes, suggesting that the ant may be immobilized by a substance other than cheliceral venom. Jocque \& Dippenaar-Schoeman (1992) have reported zodariid spiders subduing termites without biting them. Additional research is needed to determine whether that is the case in Galianoella, but it is not entirely unlikely that the unsclerotized cheliceral patches contain special glands that help in prey capture.

The laroniine Eilica Keyserling 1891, another ant-catching gnaphosoid spider sympatric with Galianoella (collected at El Hongo and Chuscha), also has peculiar cheliceral modifications. The specimens of Eilica that were actually observed catching ants were mixed with other specimens of Eilica from the same localities, but later study revealed that two species (E. trilineata Mello-Leitão 1941 and E. modesta (Keyserling 1891)) coexist there; and one of the spiders was found eating a worker of Acromyrmex striatulus. The ant- 
catching behavior of Eilica (so far unknown), however, is quite different from the cautious behavior of Galianoella: the spider quickly ran onto the ant's head, bit the base of an antenna, quickly released the ant, and waited by the side for the ant to die (or at least, to become motionless; this occurred within a few seconds). The Laroniinae are characterized by a laminar (almost membranous) keel in the cheliceral margin. Callilepis Westring 1874, the other genus in the subfamily, has been reported to capture ants in a similar way (Heller 1976); and it is most likely that the cheliceral keel, synapomorphic for the subfamily, plays a special role here.

Distribution.-Southern Salta and northwestern Tucumán, in northwestern Argentina. The six known localities are all in two valleys which form part of a larger system of valleys, rather isolated from lower, more forested habitats. Relatively careful collecting in other parts of Salta and Tucumán has yielded no specimens of Galianoella, which may be restricted to these valleys.

Other specimens examined.-ARGENTINA: Salta: Chuscha, $6 \mathrm{~km}$ NW Cafayate, 10 January 1995 (P. Goloboff, C. Szumik), 29 (FIML); 18 April 1995 (P. Goloboff, C. Szumik), 2 (FIML) 20 November 1995 (P. Goloboff), 20 (FIML), 10 (MACN), 1 ㅇ (AMNH). El Hongo, 2 km S Alemania, July 1995 (M. Ramírez, P. Goloboff) 1 (MACN). La Salamanca, 3 km S Alemania, 19 February 1996 (P. Goloboff, C. Szumik), 20 (FIML). Ruta Nacional 40, km. 1026, 6 km S Tolombón, 18 April 1995 (P. Goloboff, C. Szumik), 1 ㅇ 3 juvs. (FIML). Tucumán: Amaicha del Valle, 10 January 1995 (P. Goloboff, C. Szumik), 1 juv. (FIML).

\section{ACKNOWLEDGMENTS}

I am grateful to Norman Platnick for the loan of comparative specimens of Gallieniel- la, Legendrena, and Drassodella; to C. Sutton, A. Brescovit, and A. Bonaldo for making the type specimen of Azilia leucostigma available; to Norman Platnick and Martín Ramírez for their critical comments on the manuscript; to the Consejo Nacional de Investigaciones Científicas y Técnicas for supporting my research; and to F. Cuezzo for identifying ant remains.

\section{LITERATURE CITED}

Goloboff, P.A. 1995. A revision of the South American spiders of the family Nemesiidae (Araneae, Mygalomorphae). Part I: Species from Peru, Chile, Argentina, and Uruguay. Bull. American Mus. Nat. Hist. 224:12-189.

Heller, G. 1976. Zum Beutefangverhalten der ameisenfressenden Spinne Callilepis nocturna (Arachnida, Araneae, Drassodidae). Entomol. Germanica, 3:100-103.

Jocque, R., and A.S. Dippenaar-Schoeman. 1992. Two new termite-eating Diores species (Araneae, Zodariidae) and some observations on unique prey immobilization. J. Nat. Hist., 26:14051412.

Mello-Leitão, C. 1941. Las arañas de Córdoba, La Rioja, Catamarca, Tucumán, Salta y Jujuy. Rev. Mus. La Plata (nueva serie, Zool.), 2:99-198.

Platnick, N. 1984. Studies on Malagasy spiders. 1. The family Gallieniellidae (Araneae, Gnaphosoidea). American Mus. Nov., 2801:1-17.

Platnick, N. 1990a. Spinneret morphology and the phylogeny of ground spiders (Araneae, Gnaphosoidea). American Mus. Nov., 2978:1-42.

Platnick, N. 1990b. A new species of Legendrena (Araneae: Gallieniellidae) from Madagascar. J. New York. Entomol. Soc., 98:499-501.

Manuscript received 1 September 1997, revised 14 January 1999. 